\title{
Iklan Sebagai Media Kritik Sosial (Pesan Simbolik Iklan Kretek Djarum 76 Seri Jin)
}

\author{
Firdaus Azwar Ersyad, Yoga Rarasto Putro \\ (firdaus.azwar@usm.ac.id,yoga_animator@yahoo.com) \\ Pengajar Ilmu Komunikasi USM, Alumni Pascasarjana IKJ
}

\begin{abstract}
The presence of television advertising is a prayer one way to manufacturer for review introduce and selling products for society. Regarding the regulation of advertising especially cigarettes and tobacco products manufacturer in order to encourage creative hearts introducing more on audience their product. As a result, the creativity in the hearts smoking ads aimed lifting product image so not operate direct products display. Singer study originated from the interest against visualization advertisements Djarum 76 series java jin has its own peculiarities compared to other products. Zoom the one consolation is not revealed that an advertiser is selling products. Views are interpreted by different groups various ad viewers, but the views can be grouped into some basic ideas
\end{abstract}

Kata Kunci: Iklan Djarum 76, Kritik Sosial, Citra Produk.

\section{Pendahuluan}

"Indonesia surga bagi industri rokok, tapi neraka buat rakyatnya," ucap Hasbullah Thabrany (2015), Ketua Pusat Kajian Ekonomi dan Kebijakan Kesehatan Universitas Indonesia. Harga rokok di Indonesia masih sangat murah jika dibandingkan negara lain, termasuk negara tetangga, seperti Singapura, Malaysia, Thailand, dan Laos. Di Singapura misalnya, harga rokok jika dirupiahkan sekitar Sembilan puluh ribuan hingga seratus ribuan, begitu pula di Malaysia. Hal yang berbeda justru ditemui di Indonesia yang menjual berbagai jenis rokok dengan harga yang murah. Harga yang dtawarkan kurang lebih mulai dari enam ribuan hingga dua puluh ribuan rupiah saja. Bea cukai tembakau yang rendah di Indonesia merupakan faktor penting yang membuat industri rokok dapat tumbuh subur. Hal ini tentu saja memberi ruang yang sangat luas terhadap produsen baik kecil hingga besar.

Faktor lain yang turut mendukung adalah animo tingkat konsumsi masyarakat Indonesia yang cenderung tinggi terhadap rokok. Mulai dari golongan tua, dewasa, hingga remaja saat ini telah banyak yang menempatkan rokok sebagai bagian dari gaya hidup. Gaya hidup tersebut turut menentukan jenis rokok apa yang dianggap paling nikmat untuk dikonsumsi oleh tiap golongannya. Salah satu hal yang membentuk ketertarikan tersebut adalah iklan-iklan yang tersebar di berbagai media cetak maupun elektronik. Menurut Ezki Suyanto (2013), Iklan rokok telah diketahui merupakan daya tarik yang baik, terutama bagi remaja dan anak-anak 
untuk

mencoba

rokok

(http://health.kompas.com/read/2013/05/3

1, 2015). Berbagai regulasi yang ditetapkan pemerintah tentang iklan rokok seperti pengaturan jam tayang, visualisasi iklan, serta pictoral health warning (PHW) belum cukup efektif menekan angka privalensi perokok lama maupun baru. Harga yang murah serta iklan-iklan yang sangat menarik diduga menjadi faktor terbesar yang mendukung Indonesia sebagai surganya rokok.

Perkembangan iklan tidak terlepas

dari kemajuan bidang teknologi informasi. Kemajuan ini telah melahirkan teknologi media audio visual berupa televisi. Televisi menurut etimologinya berawal dari kata "tele" yang berarti jauh, dan "vision" yang berarti penglihatan atau wawasan. Penemuan ini bahkan disejajarkan dengan penemuan roda karena kehebatannya dalam pembentukkan peradaban dunia (http://repository.amikom.ac.id, 2015). Televisi sebagai media audio visual mampu menjadi wahana dalam propaganda ideologi, pemikiran dan budaya.

Televisi dan radio sebagai produk teknologi komunikasi massa merupakan media komunikasi dengan menggunakan teori komunikasi linear atau satu arah. Menurut Djamal (2011), teori komunikasi satu arah (one way direction) merupakan proses perjalanan suatu pesan dari sumber (source) kepada receiver (Djamal \& Fachruddin, 2011: 69). Dalam model teori komunikasi satu arah, receiver atau penerima pesan merupakan objek pasif yang tidak memungkinkan melakukan feedback terhadap source atau pengirim pesan. Hal ini mengakibatkan televisi diyakini memiliki efektifitas dalam melakukan propaganda terhadap penonton atau audience. Djamal mencontohkan propaganda di dunia politik dalam usaha mendeskreditkan kelompok Islam oleh pihak barat dengan memunculkan sosok Osama Bin Laden. Tokoh yang disebut-sebut sebagai penggerak aksi terorisme oleh pihak barat ini seakan tidak dapat mereka sentuh. Maka tidak tertutup kemungkinan hal ini merupakan bentuk pembenaran terhadap suatu hal yang sebenarnya tidak ada (Djamal \& Fachruddin, 2011: 75). Keunggulannya menyampaikan pesan secara audio visual membuat banyak produsen produk dan jasa berlomba mengiklankan produk-produknya di televisi. Informasi yang disampaikan melaui televisi baik hiburan, siaran berita, maupun iklan mampu diserap secara audio dan visual. Sebagai produk budaya populer, iklan televisi memiliki kekuatan yang cukup kuat dalam mempengaruhi citra produk dan persepsi di benak masyarakat terhadap produk yang ditawarkan. Karena kemampuannya dalam membentuk persepsi, televisi saat ini tidak terlepas dari berbagai kepentingan para pemilik modal dalam industri pertelevisian. Televisi menjadi alat atau senjata ampuh dalam kepentingan politik, industri, ekonomi dan pembangun citra. Efektifitas tersebut tentu saja tidak terlepas dari perkembangan teknologi komunikasi khususnya televisi yang mendukung percepatan penyampaian pesan pada khalayak.

Kemajuan di bidang penyiaran mendorong teknologi televisi berkembang dengan cepat. Jhon L. Blaird (1927) berhasil mentransmisikan sinyal 
siaran televisi pertama, dan digunakan BBC pada 1929. Di Indonesia, stasiun televisi pertama TVRI berhasil mengudara dan menyiarkan Asian Games IV pada Agustus 1962. Setelah itu, muncul berbagai stasiun televisi swasta nasional seperti RCTI (1987), SCTV (1989), TPI (1990) dan diikuti berbagai stasiun lainnya (Djamal \& Fachruddin, 2011: 25, 35). Melalui televisi, peradaban masyarakat dunia mulai berkembang dengan pesat karena informasi-informasi di seluruh dunia dapat dengan mudah diketahui melalui pesawat televisi. Selain itu, masyarakat tidak perlu lagi bersusah payah untuk mendapatkan hiburan di gedung-gedung pertunjukkan karena televisi juga menyiarkan acara-acara hiburan. Dalam bidang perekonomian dan industri, televisi memiliki peran penting sebagai media yang menyiarkan iklan. Keunggulannya mendukung pertumbuhan industri dan perekonomian dunia sangat pesat.

Televisi dalam pengertian normatifnya dipahami sebagai sebuah media komunikasi yang menampilkan fungsi hiburan, informasi/ berita, dan juga iklan. Pada kenyataannya, dalam industri pertelevisian fungsi-fungsi tersebut tidak dapat dilepaskan dari intervensi-intervensi kepentingan para pemilik modal. Seperti halnya industriindustri lain yang mengejar profit dari pasar demi meraup keuntungan besar. Iklan-iklan di televisi memiliki andil yang cukup besar dalam kelangsungan hidup industri pertelevisian. Menurut Damono (2013) dalam situasi demikian hidup-matinya media sedikit banyak ditentukan oleh iklan (Damono, 2013: 3). Tanpa iklan, media akan sulit bertahan terutama media-media swasta. Sehingga dapat disimpulkan, isi program dalam media televisi sangat dipengaruhi oleh pengiklan. Di sisi lain, media akan cenderung mengikuti perkembangan selera pasar untuk menarik para pengiklan. Keadaan seperti inilah yang menyebabkan media sulit berdiri sendiri dan tidak murni terbebas dari intervensi persoalan industri secara politik dan ideologi.

Seperti halnya siaran televisi dan film, iklan televisi tidak hanya mampu mengarahkan persepsi dan citra produk kepada publik, namun juga mampu merekonstruksi realitas, budaya-budaya, dan ideologi baru tentang gaya hidup pada publik. Gaya hidup yang ditampilkan dalam iklan televisi dengan cepat mampu menyebar ke seluruh pelosok negeri. Akibatnya, arus persebaran budaya tidak lagi terbatas oleh tembok atas ruang dan waktu. Gaya hidup atau style yang ditampilkan dalam iklan kerap kali dianggap sebagai gaya hidup modern perkotaan. Hal inilah yang mempengaruhi bagaimana perkembangan budaya populer melalui iklan televisi atau TVC (TV Commerce). Budaya dan konsep-konsep klasik-tradisional di pedesaan berpotensi semakin tergerus keberadaannya karena serangan gaya hidup modern perkotaan yang cukup kuat mempengaruhi para generasi mudanya.

Iklan televisi secara harfiah merupakan suatu bentuk penyampaian ide, informasi atau gagasan melalui siaran televisi sebagai wahana atau kendaraan. Iklan tidak selalu berkaitan dengan kepentingan kapitalis yang mementingkan keuntungan bisnis semata, tetapi dapat juga berupa himbauanhimbauan seperti halnya iklan layanan 
masyarakat (ILM). Hal tersebut sesuai fungsi khusus iklan yang mentransmisikan suatu ide atau gagasan kepada khalayak luas. Dari tayangan televisi hingga cover majalah mengindikasikan citra media yang berorientasi pada bisnis dan gaya hidup konsumtif (Wibowo, 2007: 38). Saat ini iklan dalam media televisi di Indonesia pun lebih banyak didominasi oleh iklaniklan produk yang bersifat membudayakan gagasan-gagasan konsumerisme dan kapitalisme. Iklan rokok ditampilkan sangat berbeda dengan iklan-iklan produk lainnya, hal ini disebabkan oleh adanya regulasi pemerintah yang mengatur iklan tersebut. Seperti yang kita ketahui, bahwa iklan rokok di televisi cenderung menampilkan sesuatu yang bias dan tidak terkait dengan produk yang dijual. Dalam hal ini, iklan tidak menampilkan produk dengan jelas, sehingga makna iklan harus dimunculkan secara implisit. Sedangkan untuk iklan-iklan produk lain, biasanya pesan ditayangkan secara vulgar (jelas) dan bersifat persuasif. Hal yang berbeda dari tampilan iklan-iklan rokok membuat Iklan ini terbilang sangat canggih dan shopisticated dalam penayangannya. Hal inilah yang menyebabkan pembuat iklan rokok dituntut lebih kreatif dalam memvisualisasikan produk rokok agar tetap dapat diterima masyarakat dan tidak melanggar undang-undang penyiaran serta peraturan yang berlaku. Konsep yang bias dari iklan rokok tersebut juga berlaku terhadap media-media lainnya. Terkadang dalam keseharian dapat kita lihat bagaimana nama-nama atau brand rokok menghiasi berbagai event perlombaan dan panggung musik baik di Perkampungan atau Perkotaan. Adapun pertanyaan dari latarbelakang yang telah diuraikan sebelumnya yang terkait iklan, yaitu; secara garis besar, bagaimanakah iklan-iklan djarum 76 seri jin tersebut ditampilkan? Makna apakah yang muncul sebagai kritik sosial dalam iklan djarum 76 seri jin?

\section{Metodologi Penelitian}

Dalam iklan djarum 76 yang menggunakan figur Jin Jawa sebagai ikon, memberikan suatu bentuk konstruksi baru dalam iklan rokok di Indonesia. Iklan rokok biasanya menggunakan konsep - konsep petualangan yang menantang untuk menunjukkan sisi maskulinitas. Gaya dan dagelan konyol khas pertunjukan teater tradisi rakyat Jawa yang dibangun dalam iklan menjadi kekuatan yang mampu menyihir penonton untuk terus mengikuti alur iklan. Dagelan dan parodi yang disajikan tidak hanya segar dan menghibur, namun juga sarat akan nilai dan kritik sosial. Kritik-kritik sosial yang disampaikan merupakan sindiran-sindiran terhadap patologi sosial atau penyakitpenyakit di masyarakat.

Melalui penelitian ini, akan dikupas bagaimana tanda-tanda yang khas menghasilkan berbagai pemaknaan dari pemirsa iklan. Metodologi yang digunakan dalam penelitian adalah kualitatif deskriptif, dengan melihat berbagai tanda besar yang menonjol dan sering tampak sebagai benang merah iklan djarum 76 seri jin. Sebagai sumber data primer dalam penelitian adalah kumpulan video-video iklan TVC djarum 76 seri jin. Sebagai referensi atau data pendukung yaitu berbagai literatur dari buku-buku, referensi internet, serta hasil penelitian-penelitian yang sudah ada sebelumnya. Teknik penelitian yang akan 
dilakukan adalah dengan mengamati seluruh video iklan djarum 76 seri jin hingga beberapa kali. Setelah itu akan ditemukan benang merah dari seluruh iklan terkait strategi dan juga visualisasi. Kemudian, peneliti akan menganalisis garis besar simbol-simbol iklan tersebut menggunakan ilmu semiotika atau pemaknaan sebagai pisau bedah.

\section{Hasil dan Pembahasan}

Pada akhir tahun 90an, dari data yang diperoleh, iklan Djarum 76 telah menggunakan simbol-simbol budaya lokal sebagai tema pada tampilan iklan. Pada saat itu, iklan banyak mengangkat berbagai simbol-simbol yang menandakan tempat atau budaya tertentu. Konsep tersebut memperkenalkan pada publik tentang berbagai kearifan lokal Indonesia baik berupa tempat, hasil bumi, rumah adat, upacara, dan juga kesenian tradisi. Akan tetapi, iklan djarum 76 saat itu lebih banyak mengangkat berbagai simbol budaya yang ada di pulau Jawa, Bali, Kalimantan, dan Sumatra. Iklan menggambarkan seseorang atau sekelompok pria yang sedang berwisata ke suatu daerah tertentu, kemudian menemukan dan menikmati berbagai kearifan lokal di sana. Kemudian, iklan djarum 76 bertransformasi dengan berkonsep komedi. Iklan tersebut terlihat sangat sederhana bahkan terkesan murah. Iklan ini memperlihatkan seorang reporter happy news yang sedang meliput berita dan melakukan wawancara. Kekuatan utama iklan tersebut adalah pada konten dan dialog wawancara serta ekspresi dari sang reporter. Dialog yang lucu memberikan hiburan tersendiri bagi pemirsa iklan terlepas dari tampilannya yang murah dan sangat sederhana untuk sekelas iklan rokok. Uniknya, dialog menggunakan logat Jawa disertai katakata ekspresif yang sangat dekat dengan masyarakat Jawa.

Sekitar tahun 2009 Djarum 76 mulai melakukan inovasi dan transformasi dengan menggunakan ceritacerita pendek sebagai unsur komikal atau komedinya. Djarum 76 menggunakan cerita tentang perjalanan sesosok Jin Jawa sebagai ikon iklan. Konsep tersebut masih digunakan hingga kini.

Iklan djarum 76 berbentuk parodi atau dagelan dengan menggunakan ikon Jin Jawa yang lucu beserta unsur-unsur budaya Jawa yang cukup kental. Jin Jawa dalam iklan digambarkan memiliki kesaktian untuk mengabulkan segala permintaan bagi siapapun yang bertemu dengannya, akan tetapi selalu saja berakhir dengan kekonyolan. Hal inilah yang menimbulkan kelucuan-kelucuan tersendiri dari iklan. Dalam iklan djarum 76 , nilai maskulinitas diwakili oleh ikon Jin Jawa pria yang memiliki kesaktian untuk mengabulkan permintaan. Cerita yang ditampilkan tentu saja telah melalui berbagai pertimbangan khususnya dalam hal product positioning.

Berdasarkan pada apa yang telah dijelaskan dalam situs perusahaan, maka jelaslah jika product positioning yang diacu oleh produk djarum 76 mengarah pada selera masyarakat Jawa, Sumatra, Kalimantan, dan Bali. Dengan pangsa terbesar masyarakat Jawa kelas menengah ke bawah, tentu konsep merakyat menjadi salah satu acuan bagaimana iklan djarum 76 harus dibuat.

"Menurut Bapak Ronald Theo Lesmana selaku Marketing Creative di PT. Sumber Cipta, selain untuk membedakan dengan konsep iklan rokok yang lain, sosok Jin yang lucu dimunculkan sebagai ikon 
dalam iklan Djarum 76 agar para penonton bisa cepat menangkap isi pesan iklan ini, mengingat iklan ini hanya berdurasi 28 detik atau dengan kata lain sebagai reminder.Berdasarkan slogan "Yang Penting Hepiii...", iklan ini dibuat dengan konsep cerita ringan dan berisi lelucon-lelucon yang bisa didengar di sekitar kita sehari-hari serta disesuaikan dengan sasaran iklan ini yaitu kalangan masyarakat sub-urban" (Suhartono, 2013).

PT. Sumber Cipta merupakan perusahaan distribusi yang bekerjasama dengan PT. Djarum untuk pemasaran produk-produknya. Tidak hanya menjadi fungsi distribusi, namun juga fungsi marketing guna memperkenalkan produkproduk PT. Djarum. Konsep pendekatan yang diusung menurut sumber tersebut tampak memberikan citra atau image yang "memihak" kepada golongan masyarakat kelas menengah ke bawah (sub-urban). Parodi berupa kritik sosial yang cair sangat dekat dengan kehidupan masyarakat perkotaan maupun pedesaan pada strata atau golongan masyarakat menengah ke bawah. Kedekatan ini diperkuat dengan kelucuan-kelucuan dari tokoh sentral, Totos Rasiti (pemeran Jin pria). Kelucuan yang ditampilkan membuat penonton betah untuk mengikuti tiap adegan-adegannya, walaupun apa yang ditampilkan tidak ada hubungan langsung dengan produk yang diiklankan. Tampilan yang bias seperti ini sangat lazim ditampilkan oleh produkproduk rokok lainnya. Selain rokok, tentu kita masih ingat dengan berbagai kegiatan seperti "gerakan seribu langkah susu Anlene", "gerakan senyum sehat Pepsodent", "gerakan air bersih Indonesia Aqua", dan berbagai kegiatan saat mudik lebaran oleh produk jasa seluler.
Kegiatan-kegiatan tersebut merupakan cara untuk mempromosikan citra atau brand image tentang produk pada konsumen atau masyarakat luas.

Dalam membentuk citra terhadap produk yang ditawarkan, iklan merekayasa (simulasi) dan mereproduksi realitas agar produknya bisa laku di pasaran. Dalam membuat iklan, pengiklan setidaknya harus merancang target market dan segmentasi konsumen yang dituju atau lingkungan periklanan. Pengiklan harus mampu mengantisipasi setiap perubahan lingkungan periklanan dengan terus memodifikasi strategi periklanan karena lingkungan yang begitu dinamis (Lee \& Johnson, 2011: 29). Perubahan biasa terjadi pada negaranegara yang multikulturalis seperti di Indonesia. Untuk mengantisipasinya, pengiklan harus mampu bersikap reaktif dan proaktif terhadap gejala-gejala di lingkungannya. Keadaan ini menimbulkan sebuah pendapat tentang matinya sebuah realitas pada iklan. Strategi marketing menciptakan sebuah realitas buatan yang digunakan untuk merekayasa suatu keadaan tertentu dalam iklan. Artinya, pengiklan cenderung merekayasa realitas dengan merekonstruksi kejadian-kejadian di dunia nyata agar pesan iklan dapat disampaikan secara efektif.

Iklan djarum 76 seri jin sarat akan kritik sosial di dalamnya. Kritik sosial ditampilkan secara eksplisit maupun implisit sehingga diperlukan kejelian pemirsa iklan saat melihatnya. Setiap elemen di dalam iklan bisa dimaknai secara beragam, baik sebagai hiburan, kritik, maupun pencitraan produk. Pada bagian opening, dibuka dengan tampilan awan dan juga matahari yang posisinya 
selalu berubah di tiap versinya. Mayoritas informan sebagai pemirsa iklan, tidak melihatnya memiliki makna lain kecuali sebagai petanda iklan djarum 76. Elvida mengungkapkan bahwa "jingle di bagian awal mampu menarik perhatian untuk melihat iklan lebih dalam. Djarum 76 diasosiasikan seperti matahari yang muncul di antara awan-awan". Elvida tidak hanya menerima kode dominan jingle berupa ikon pembuka iklan djarum 76, namun menegosiasikan makna lain berdasarkan tanda-tanda visual di dalamnya. Penambahan makna konotatif tersebut berupa asosiasi visual matahari sebagai sosok representatif dari djarum 76. Proses negosiasi tersebut merupakan tingkatan pertengahan dari proses decoding. Hal ini antara lain dipengaruhi oleh bagaimana proses representasi yang terjadi dalam melihat suatu objek berdasarkan kemiripan dengan objek lain atau perbedaan dengan objek lainnya. Persepsi ini, dipahami sebagai persepsi kritis yang menghasilkan diskusi-diskusi baru terhadapnya.

Dari sisi visual, tampilan awan dan matahari tampak berbeda-beda bahkan terasa mengikuti tema apa yang akan disajikan. Pada dasarnya, langit mampu merefleksikan sebuah makna kebebasan sekaligus misteri. Pemandangan langit memberikan nuansa yang luas, bahkan mampu membangkitkan imajinasi yang berbedabeda. Seperti halnya visual awan, senantiasa memberikan kesan yang misterius, tertutup, serta dinamis. Bentuk awan, kerap digunakan sebagai bagian dari adegan pembuka dalam pertunjukan wayang kulit. Awan ditampilkan dalam bentuk gunungan. Bahkan, awan dalam cerita wayang maupun dongeng sering digunakan sebagai visual pembatas antara alam manusia yang nyata dan alam ghaib tempat bersemayam para Dewa serta Jin. Secara sains, awan merupakan bagian dari rantai proses atau siklus di muka bumi. Agar menjadi awan, maka air harus menguap ke udara dengan bantuan energi panas matahari. Uap tersebut kemudian terbawa angin dan berkumpul dalam lapisan atmosfer dan membentuk sebuah awan yang menutupi bumi sehingga gelap. Akan tetapi, ketika telah mencapai suatu titik ketinggian tertentu, maka suhu udara pun akan menurun. Suhu yang menurun akan menimbulkan efek dingin yang kemudian membuat awan kembali mencair dan jatuh ke bumi sebagai rintik hujan. Hujan yang jatuh ke bumi akan memberikan kesuburan serta nutrisi yang cukup untuk menumbuhkan tanaman serta mempertahankan kehidupan makhluk-makhluk di muka bumi. Selain itu, tentu saja menimbulkan kesejukan di bumi setelah terhampar terik matahari. Oleh karena itu, kita perlu mencermati dan meneladani sifat-sifat awan. Awan dalam wayang kulit menurut Suyanto, menunjukkan sebuah gambaran proses bahwa untuk mencapai keberhasilan diperlukan tahapan panjang dan tidak tiba-tiba (http://suyanto.dosen.isiska.ac.id/category/karya-ilmiah, 2015). Awan memberikan sebuah refleksi tentang kehidupan yang harus senantiasa dijalani dengan kesabaran dan usaha terbaik. Sayangnya, hal ini kurang dipahami baik oleh masyarakat kita ataupun para pemimpin kita yang cenderung berpikir pragmatis dengan menghalalkan segala cara untuk mencapai tujuannya. Di luar itu, awan dan asap sangat lekat dengan cerita-cerita jin pada kisah 1001 malam. 
Pada iklan-iklan yang menceritakan tentang keserakahan seperti versi matre, jin kena tipu, pacar, kontes jin, wakil rakyat, dan kampanye jujur selalu menambahkan objek matahari di antara awan-awan. Matahari telah diketahui sebagai pusat tata surya dan penghasil energi bagi segala kehidupan di Bumi. Dalam berbagai budaya, simbol matahari diyakini memiliki makna-makna khusus. matahari sangat erat berhubungan dengan kekuatan, vitalitas, dan semangat. Selain itu, Matahari mewakili sifat-sifat penguasa dan otoritas. Egoisme dalam diri dilambangkan dengan Matahari, disebabkan oleh cahayanya yang berwarna keemasan, maka Matahari dianggap mewakili simbol karakter emas (http://siradel.blogspot.com/2011/02/filos ofi-simbol-simbol-planetary,2015).Visual awan dan matahari dalam pembuka iklan disimpulkan membawa pesan-pesan kritik sosial yang akan ditampilkan di dalam iklan.

Sebagai sebuah iklan yang banyak mengangkat elemen budaya Jawa untuk kemasannya, maka tidak terlepas dari filosofi-filosofi yang ada dalam budaya itu sendiri. Folosofi-filosofi tersebut menjadi dasar bagaimana pandangan penonton terhadap apa yang diperlihatkan iklan. Seperti yang telah diketahui, bahwa guyonan dalam iklan sangat khas bergaya dagelan Jawa dan dekat dengan kehidupan masyarakat sehari-hari. Latar belakang para informan yang merupakan orang Jawa turut menentukan makna apa yang terkandung dan informasi apa yang sedang disampaikan oleh iklan.

Orang Jawa memiliki hubungan yang tak terpisahkan dengan kepercayaan serta mistikisme. Hal tersebut mengandung berbagai nilai-nilai kearifan lokal seperti; tradisi, ritual, filsafat, norma, etika, adat istiadat yang mengatur hubungan dengan Tuhan, alam dan kehidupan sosial. Visualisasi dalam iklan djarum 76 seri Jin, merupakan sebuah implementasi dari nilai-nilai filsafat Jawa. Salah satu contoh filsafat Jawa di dalam iklan terdapat dalam ungkapan "nrimo ing pandum" yang berarti menerima apa yang menjadi haknya. Ungkapan ini mengajarkan untuk selalu bersyukur dan tidak serakah (Rohmadi \& Hartono, 2011: 282). Keserakahan hanya membawa petaka dan persepsi yang buruk tentang dirinya, hal ini banyak diangkat sebagai topik atau tema dalam iklan. Selalin itu, terdapat ungkapan "aji mumpung" yang bermakna "ilmu mumpung" dan "yen wania ing gampang, wedia ing ewuh sabarang nora tumeka" yang berarti "jika hanya berani dengan yang mudah dan takut yang susah, maka segala cita-cita tidak akan terwujud" (Hariwijaya, 2014: 8 \& 107). Hal tersebut juga menjadi bagian dari topik yang banyak diangkat dalam iklan-iklan djarum 76 seri Jin. Falsafah-falsafah tersebut seringkali dihubungkan dengan berbagai konflik yang melibatkan manusia dengan lingkungan serta takhayul.

Orang Jawa hingga saat ini sebagian dikenal masih cukup percaya pada hal-hal mistik yang dianggap memiliki kekuatan tuk mengabulkan permintaan. Bagi masyarakat Jawa, kehidupan tidak pernah lepas dari hal-hal yang bersifat ghaib. Masyarakat Jawa yang sangat tergantung pada mistikisme disebut kejawen. Masyarakat kejawen mempercayai bahwa mereka merupakan keturunan Dewa-Dewi. Dalam 
kosmogoni kejawen, menurut tantu panggelaran, Dewi Sri dan Dewa Wisnu pernah diminta turun ke arcapada untuk menjadi nenek moyang orang Jawa. Karena berasal dari kalangan Dewa, maka kaum kejawen menganggap dirinya memiliki tingkat sosial tinggi (Endraswara, 2006: 1 - 2). Maka, masyarakat kejawen merupakan bagian tradisional masyarakat Jawa yang memiliki tingkat spiritualitas dan religiusitas tinggi. Bagi mereka, mistik menjadi hal yang tabu untuk dipisahkan karena, tanpa mistik maka kejawen akan pudar. Masyarakat Jawa pada umumnya pun sebenarnya masih memiliki tingkat kepercayaan tinggi terhadap mistik dan mitos. Hal ini karena masyarakat Jawa memiliki kultur yang sama yang diwariskan dari para leluhur. Dalam kehidupan sehari-hari, masyarakat Jawa masih percaya dengan tempat-tempat kramat yang dihuni makhluk halus, takhayul, upacara-upacara tradisional, adat, dan tentang bagaimana memperlakukan anggota keluarga yang meninggal. Tingkat kepercayaan orang Jawa yang sangat tinggi terhadap mistik kemudian diaktualisasikan dalam sosok jin Jawa djarum 76. Gambaran mengenai masyarakat beserta kritik sosial tersebut disampaikan melalui parodi menghibur dari iklan djarum 76 seri jin. Parodi ditampilkan melalui konflik-konflik di dalamnya.

Secara keseluruhan, para informan melihat konflik-konflik sosial yang ditampilkan secara konten yang dibawakan tidak hanya mengandung hiburan, tetapi juga kritik sosial. Kritik sosial menempati ruang-ruang di dalam konflik yang diperlihatkan oleh perilaku jin djarum 76 dengan lingkungan sosialnya. Pemahaman masing-masing informan mengenai kritik yang dibawakan pun berbeda-beda. Pada pembahasan sebelumnya telah diketahui pendapat beberapa informan yang menyatakan bahwa konflik dalam iklan adalah bagian dari komedi yang menghibur. Pada analisis ini akan dibahas hasil-hasil interpretasi yang mempersepsikan konflik-konflik tersebut dengan kritik sosial.

Pada visualisasi konflik antara jin dan manusia, Iklan tersebut merepresentasikan sifat manusia yang ambisius dan selalu tidak puas, kehadiran beberapa golongan masyarakat menghadirkan sebuah kritik terhadap sifat-sifat tersebut. Jin sebagai sosok superior ditampilkan sebagai pihak yang selalu menang. Pernyataan itu merupakan ungkapan terhadap apa yang tersurat di dalam adegan iklan. Ungkapan tersebut sangat bergantung pada struktur yang bersifat konvensi, atau linier dengan pemahaman umum. Dengan demikian makna iklan Djarum juga mengandung pesan moral dengan memberi peringatan bahwa sesuatu yang instan itu hanya akan merugikan diri dan orang lain. Pesan moral tersebut merupakan hasil dari proses negosiasi berdasarkan hubungan sebab-akibat yang dipahami secara baku di dalam masyarakat.

Selain itu konflik manusia dan Jin merupakan sebuah wujud perumpamaan dari mitos-mitos yang menggambarkan kondisi saat ini. "penggunaan Jin Jawa dalam iklan mungkin dipengaruhi idiom yang berkembang di masyarakat bahwa sekarang merupakan jaman edan atau banyak orang-orang yang seperti kerasukan Jin. Hal ini juga menjadi ciri 
khas yang membedakannya dengan produk lain". Pernyataan tersebut menghubungkan makna iklan ke dalam metafora-metafora yang berkaitan dengan mitos. Dalam hal ini Iklan dihubungkan dengan representasi tentang "kekacauan" dunia dengan mitos-mitos yang akrab dengan masyarakat yaitu jaman edan dan kerasukan Jin. Pandangan ini sejatinya telah melewati beberapa proses pemaknaan sebelumnya. Dengan demikian, bahwa konflik manusia dan Jin dalam iklan mewakili sebuah "kegilaan". Kegilaan tersebut dilatarbelakangi oleh perilaku manusia yang sering bertindak semena-mena, kriminal, dan seringkali tidak logis. Representasi ini diungkapkan secara metafora sebagai jaman edan, atau jaman gila. Selain itu, representasi kegilaan juga diungkapkan melalui bentuk metafor kerasukan Jin. Kegilaan dan kerasukan memiliki hubungan struktural linier atau sintagmatis. Sedangkan kerasukan dan Jin merupakan sebuah keterkaitan kondisional. Sehingga dapat disimpulkan bahwa makna terkuat dalam iklan itu bersifat mitos.

Dengan demikian maka dapat disimpulkan bahwa iklan menggunakan humor atau guyonan ringan untuk menarik perhatian sekaligus hiburan. Humor yang ditampilkan merupakan refleksi kejadian sehari-hari yang dekat dengan masyarakat. Iklan menggunakan kaidah-kaidah teater tradisi rakyat untuk menampilkan cerita di dalamnya. Ceritacerita tersebut ditampilkan dalam bentuk konflik interaktif dari sang ikon produk dengan lingkungannya, dan menimbulkan premis tertentu. Mengenai konsep dan tampilan, iklan mengakulturasikan kebudayaan Timur Tengah dan Jawa sebagai hal yang populer di mayarakat.

\section{Kesimpulan}

Kesimpulan paada penelitian ini adalah bahwa salah satu strategi beriklan produk rokok itu dengan memanfaatkan konsep-konsep yang telah tumbuh di dalam hiburan rakyat. Sebagaimana terlihat dalam iklan tersebut, banyak menggunakan kaidah-kaidah seni pertunjukkan rakyat. Iklan yang menghibur ini menjadi inti strategi coding yang dilakukan pengiklan dengan tetap mentautkannya dengan konsep yang lucu, unik, tradisional, serta merakyat sehingga memunculkan image sebagai produk yang berharga murah dan terjangkau untuk kalangan menengah ke bawah. Djarum, sebagai sebuah brand dari produk-produk rokok yang sudah terkenal sejak lama menjadikannya tidak asing, dan telah terpercaya bagi masyarakat.

Melalui penelitian ini, telah membuka berbagai ruang diskusi mengenai iklan rokok kretek djarum 76 khususnya. Diskusi dapat dilanjutkan oleh penelitian lain pada studi tentang makna-makna khusus yang disampaikan melalui narasi di setiap tema iklan, pergeseran citra budaya antara Jawa klasik dengan populer seperti yang disampaikan oleh iklan dan tentang akulturasi budaya Timur Tengah di dalam iklan. 


\section{Daftar Pustaka}

Barthes, Roland. (2010). Imaji, Musik, Teks (Analisis Semiologi Atas Fotografi, Iklan, Film, Musik, Alkitab, Penulisan dan Pembacaan Serta Kritik Sastra), Terj. Agustinus Hartono. Yogyakarta: Jalasutra.

Barthes, Roland. (2007). Membedah Mitos-Mitos Budaya Massa: Semiotika atau Sosiologi Tanda, Simbol, dan Representasi. Terj. Ikramullah Mahyuddin. Yogyakarta: Jalasutra.

Bayuadhy, Gesta. (2015). Tradisi-Tradisi Adiluhung Para Leluhur Jawa (Melestarikan Berbagai Tradisi Jawa Penuh Makna), Yogyakata: Dipta.

Damono, Sapardi Djoko. (2012). Alih Wahana: Editum.
Damono, Sapardi Djoko. (2013). Kebudayaan (Populer di Sekitar) Kita: Editum.

Diandini Nata Pertiwi dkk. "Representasi Orang Jawa Dalam Iklan Televisi Djarum 76" dalam http://www.fisip.undip.ac.id, diunduh tanggal 14 April 2015.

Djamal, Hidajanto \& Andi Fachruddin. Dasar-Dasar Penyiaran (Sejarah, Organisasi, dan Regulasi), Jakarta: Kencana, 2011.

Endraswara, Suwardi. Mistik Kejawen (Sinkretisme, Simbolisme, dan Sufisme Dalam Budaya Spiritual Jawa), Yogyakarta: Narasi, 2006.

Eva Marsteffy Suhartono. "Analisis Deskriptif Pemaknaan Iklan Djarum 76 versi "Wakil Rakyat" di Televisi” dalam ejournal.ilkom.fisip-unmul.ac.id, diunduh pada 10 Desember 2014. 